South European Society and Politics

\title{
The European Union, the Turkish Military and Democracy
}

\section{Metin Heper}

To cite this article: Metin Heper (2005) The European Union, the Turkish Military and Democracy, South European Society and Politics, 10:1, 33-44, DOI: 10.1080/13608740500037924

To link to this article: https://doi.org/10.1080/13608740500037924

册 Published online: 02 Dec 2009.

Submit your article to this journal ๘

Џ Article views: 767

4 Citing articles: 15 View citing articles 지 


\title{
The European Union, the Turkish Military and Democracy
}

\author{
Metin Heper
}

The military in Turkey has been both the subject and the object of modernization as Westernization. In the process it came to occupy a prominent place in the Turkish polity, acting as the guardian of the premises upon which the Turkish Republic was based. In the post-1960 period it took power into own hands several times. Yet, the military interventions in question were made to 'save the democracy from itself' and not for the purpose of setting up a long-term military rule. Over the years, the military became less enthusiastic about intervening in politics. In recent years, the military's extrication from politics altogether gained a new momentum as a consequence of Turkey's bid to become a full member of the EU.

Keywords: Turkey; Europeanization; Military; Democracy; Atatürkism

\section{Turkey, Europe, and the Military}

Turkey's encounters with Europe date back to the second part of the fourteenth century, and gradually led to an aspiration for the Europeanization of identities in Turkey. ${ }^{1}$ In 1361 Sultan Murat I captured Edirne (Adrianople). The Ottomans continued to be successful in their military pursuits in Europe until the Treaty of Karlowitz in 1699. Sultan Mehmet II (The Conqueror) (r. 1444, 1451-81) knew Latin and Greek. He invited the Italian painter Gentile Bellini and had his portraits made. It was also during his reign that secular law codes took their places alongside the Shari'a. As their empire expanded in Europe as far as Hungary, the Ottomans found themselves in the midst of European politics. Francis I of France several times asked for the help of Süleyman I (The Magnificent) (r. 1520-66) against the Hapsburgs of Austria. During the reign of Süleyman I, numerous new secular laws were enacted that regulated security and governmental matters as well as the economy.

In addition to their contacts with Europeans through war and politics and later through economics, the Muslim subjects of the Ottoman state had close relations with 
the non-Muslims in their own country. For the Ottomans did not try to assimilate the peoples of the realms they conquered. In return for paying a special head-tax (cizye), the latter were granted autonomy in such matters as religion and education. The result of this arrangement was a certain degree of mutual acculturation among the Muslim and non-Muslim subjects of the Empire. Moreover, a number of European converts introduced Western military art and techniques to the Ottoman armies. Later, in order to arrest their decline, which lasted from the end of the seventeenth century to the first part of the nineteenth century, Ottoman sultans sent emissaries to European countries to 'find out why the Europeans had become superior to them at least on the battle ground.' ${ }^{2}$ This led the Ottomans 'to emulate the ways of the infidel in order to overcome him?

Borrowing from the West first started in the military and then inevitably spread to the civil bureaucracy. Most significantly, the future generations of the Westernized military as well as the civil elite of the Ottoman Empire and the Turkish Republic graduated from the higher institutions of learning in such fields as public administration, medicine and the military sciences, which were designed in accordance with European models and opened during the last two decades of the nineteenth century.

In the process, from the last decades of the nineteenth century onwards, the military first became the object and then the subject of the Ottoman-Turkish modernization project. Mustafa Kemal (Atatürk) and his lieutenant İsmet (İnönü), both former generals, established the Turkish Republic (1923) and adopted for their country a parliamentary system of government. They rendered secularism the basic ideal of that republic. Thinking that the religious institution had been a stumbling block to sweeping reforms in the nineteenth century, Atatürk and his associates aimed at creating a new Turk who would 'think logically' by using his/her reasoning faculties instead of turning to the Book.

Not unexpectedly, the officers in Turkey also came to have an admiration for Western civilization and also for democracy, since 'the latter was an integral part of the former.' ${ }^{3}$ Officers thought the last word should belong to civilian governments for another reason too. During the period of rule by the Union and Progress Party (Ittihat ve Terakki Partisi) in 1912-18, officers were very much involved in day-today politics and this had a detrimental effect on their professionalism. The main components of the latter had always been the cohesiveness and homogeneity of the military as an institution, discipline and hierarchy, and a duty well performed (Karaosmanoğlu 1993). In the late 1940s, young officers in particular supported the Democratic Party (Demokrat Parti-DP) against the Republican People's Party (Cumhuriyet Halk Partisi-CHP) government. Officers' favourable views about democracy were reinforced following Turkey's NATO entry in 1952. The latter received further education and/or served in NATO countries. Accordingly, their viewpoints were greatly internationalized. In later years, the Turkish military also served in various peacekeeping missions that further improved its efficiency and effectiveness. 


\section{The Military and Democracy}

Yet from the early 1950s onward, that is, following the coming to power of the DP in 1950, officers began to cherish, to use Giovanni Sartori's terminology, 'rationalist' rather than liberal democracy (Sartori 1987). They began to consider themselves as the guardians of the six constitutional principles of the Turkish Republic, that is, republicanism, nationalism, secularism, populism (in the sense of looking after the welfare of the people), étatism (the state having a dominant role in the economy), and reformism-revolutionism (making, if necessary extensive, reforms in line with changing circumstances). In their submission, politics conducted in line with these principles was in the national interest and, therefore, 'rational'.

Consequently, from 1960 to the present, the military has taken power into its own hands three times (1960-61, 1971-73 and 1980-83) and on another occasion obliged a government to resign (1997). ${ }^{4}$ In each of those instances, the military did not conceive of its intervention as an anti-democratic act. In 1960, the military removed the DP from power in the wake of 'the increased authoritarianism of that party' as well as its 'giving short shrift to the principle of secularism'. As a precautionary measure, the junta first took all the DP parliamentarians into custody. As soon as it became clear that the intervention was successful, many of those parliamentarians were freed. However, they were again taken into custody (and later tried and sentenced) when a group of law professors who had been summoned by the junta, concluded that the DP parliamentarians as well as government members had lost political legitimacy.

The 1961 Constitution institutionalized the (guardianship) role of the military by creating the National Security Council (Milli Güvenlik Kurulu-MGK). The membership of this council consisted of the president of the Republic, prime minister, and ministers of foreign affairs, defence, and interior affairs as well as the chief of staff and the commanders of the army, navy, air force, and the gendarmerie. The Council was saddled with the responsibility of acting as an advisory body to the government on internal as well as external security threats to the country. In tandem with this arrangement, the Internal Service Act of the Turkish Armed Forces (also enacted in 1961) rendered the military responsible for defending both the Turkish Fatherland and the Turkish Republic as defined by the Constitution, while the Internal Service Regulations of the Turkish Armed Forces, prepared to elaborate on some provisions of the former act, stipulated that the Turkish Armed Forces should defend the country against internal as well as external threats, if necessary by force.

On the one hand, it is clear that the introduction of the MGK could lessen the possibility of future military interventions, since the military now had a legal and institutionalized means of conveying its views to government. On the other hand, the military now had reason to participate in government frequently and, furthermore, it had a legal obligation to do so 'when the country faced a grave threat and civilian governments seemed indifferent toward or unable to effectively deal with that threat'. Indeed, in all subsequent intervention, juntas argued that they were fulfilling a legal obligation (Sakallığlu 2002). 
In the 1960s and 1970s, Turkey experienced armed conflict between the radical left and right. From 1970 onwards, religiously oriented political parties began to compete for government, and in the post-1973 period they started to join coalition governments, first as junior and then senior partners, and in 2002 formed a majority government. According to the first of these political parties, the National Order Party (Milli Nizam Partisi-MNP) (1970-71), there was a basic incompatibility between the worldview of the party and the secular republic. By the time the fourth of the religiously oriented parties, the Felicity Party (Saadet Partisi-SP) was formed, that discourse was replaced by one according to which 'neither the state nor religion should interfere in the affairs of the other' (Heper 2001, p. 11). The post-November 2002 majority government of the Justice and Development Party (Adalet ve Kalkınma Partisi-AKP) in turn studiously kept religion away from state affairs (Heper forthcoming). However, the majority of the secularists, including the officers, continued to view these parties as serious threats to the republic. ${ }^{5}$ Finally, from 1984 onward, Turkey found itself involved in an armed struggle with the separatist movement of the Kurdistan People's Party (PKK) with a cost of more than 30,000 lives. Consequently, while in the wake of the 1960 military intervention the MGK was to 'offer information to government', in the aftermath of the 1971-73 intervention it 'recommended measures', and following the 1980-83 intervention, 'the government had to give top priority to the recommendations made by the MGK'.

As might be expected, the military members of the MGK became quite concerned about 'the threats that political Islam and Kurdish separatism posed for the country'. Whenever they came to the conclusion that civilian governments were not rising to the occasion, the generals proposed measures they deemed necessary; if adequate measures were not adopted, they warned the governments; and, as noted, on certain occasions they took power into their own hands or forced governments to resign.

Yet, all along, the Turkish military has not been power hungry. The top commanders tried to make sure that the 1960 'colonels' coup' should not be followed by other coups. Then they came to the conclusion that if an intervention was going to be made it should better be conducted by the generals themselves.' Also, while the 1960 interveners had, by inserting certain prescriptive provisions into the Constitution, set for themselves some grand missions including economic restructuring, the later interveners came up with limited goals. Furthermore, as the decades passed, the military became less reluctant to intervene in politics. This was because even if constitutions were amended or replaced by new ones and other measures were taken in order to 'save democracy from itself' by rendering it more 'responsible and thus more viable', once the officers returned to their barracks, politics returned to its old ways. ${ }^{7}$

Consequently, sometimes when there was a conflict of opinion between the military and civilian government—such as that between President Turgut Özal and Chief of Staff Necip Torumtay in December 1991 over the possible involvement of the Turkish military in the Gulf War - the chief of staff did not resort to a coercive action. Instead, he tendered his resignation. ${ }^{8}$ As already noted, at other times, such as the 1997 crisis, the military acted as a pressure group, though as 'first among equals', obliging 
Prime Minister Necmettin Erbakan from the religiously oriented Welfare Party (Refah Partisi-RP) to resign (Heper and Güney 2000). During the latter episode, President Süleyman Demirel, in order to prevent the political crisis from escalating, argued that the military members of the MGK were acting as top experts on security matters and not necessarily as members of the military. Then and later, the generals in question too referred to themselves in those terms. In the terminology of the introduction to this File, towards the end of the twentieth century, the process of the 'Europeanization of identities' that had started centuries earlier in the Ottoman-Turkish polity considerably improved upon the 'Europeanization of political processes' in republican Turkey.

\section{The Military and the European Union}

From 1999 onwards, following Turkey's designation by the EU as a 'candidate' country, governments in Turkey felt themselves obliged to further liberalize and democratize the political regime in conformity with the EU acquis. Among other things, the military now had to occupy a subordinate position vis-à-vis civilian governments. After all, as late as 2001, the EU Commission pointed out that 'the basic features of a democratic system exist in Turkey, but a number of fundamental issues, such as civilian control over the military, remain to be effectively addressed' (cited in Müftüler Baç, 2003, p. 433).

Initially, such a transformation in Turkish politics seemed difficult to achieve. The military thought of the issues of political Islam and Kurdish separatism as too critical to be left to civilian governments. Moreover, in recent years the military had come to have a sceptical attitude towards some of the EU countries. In their view, a number of member states were trying to legalize the PKK and politicize the Kurdish issue in Turkey. Generals were also troubled by the anti-Turkish statements made in some EU countries and, in particular, by the fact that the weapons bought by Turkey from those countries were sometimes not delivered on the 'pretext' of human rights violations in Turkey (Heper 2002, pp. 65-6).

However, the 1999-2002 coalition government and in particular, the postNovember 2002 AKP government displayed strong political will to re-structure the Turkish legal system and politics in accordance with the Copenhagen criteria with the aim of opening accession negotiations with the EU (see Müftüler Baç, this issue). Among other things, the civilian governments in question removed the military member from the State Security Courts, increased the number of the civilian members of the MGK, and more significantly rendered the MGK into a body that no longer 'recommended measures' but 'conveyed its views upon request. Meanwhile, the government did not "give priority to"' but 'assessed the views conveyed to it'. Thus, the secretariat of the MGK was deprived of its executive powers, such as requesting reports from government agencies on how they were dealing with the threats for which the MGK had recommended specific measures. These reforms were important examples of 'political Europeanization'. 
The military was of two minds concerning these reforms. There was a near consensus that they would considerably weaken Turkey's hand in its struggle against the 'lingering' twin threats of political Islam and Kurdish separatism. Yet, having always had a Western vocation and therefore a belief that at least in principle the last word should belong to civilians, and having over the last three decades become increasingly reluctant to interfere in politics, the office of the chief of staff decided to share their reservations with the government and then go along with the latter's policy. This attitude was reflected in the following statement made by the deputy chief of staff, General Yaşar Büyükanıt:

During the deliberations on the ... [last] reform package, we conveyed our views to the government. Some were accepted, others were not. Now that Parliament enacted them into law, it is our duty to comply with them. We only hope that our concerns and worries prove to be groundless (Milliyet, 11 August 2003).9

This view, however, was not shared by a number of top-ranking generals, who continued to have doubts about the ability of civilian governments to grapple successfully with the problems of political Islam and Kurdish separatism. Also, in all probability, compared to the office of the chief of staff, this latter group of generals seemed more troubled by the fact that Turkey now had a religiously oriented government whose ulterior motives were, in their view, in doubt. They thus entertained the idea that the AKP government was enthusiastic about liberalizing reforms so that they would have a freer hand to promote political Islam in Turkey. Consequently, the then Secretary-General of the MGK, General Tuncer Kılınç, the most outspoken and radical member of the latter group of generals, made the following remarks:

The changes made in the Act on the Fight against Terrorism would no longer have a deterrence effect on the perpetrators of those crimes; TV broadcasting in Kurdish would incite ethnic separatism; the admitting to Turkey of observers during elections would mean granting capitulations to foreigners (Milliyet, 25 August 2003).

As would be expected, General Kılınç_-who had earlier claimed that while he had served as the undersecretary of the ministry of defence for three years, the ministers were more interested in serving their constituents than the ministry itself (Hürriyet, 18 May 2003)—was even more critical of the reforms concerning the MGK:

[This] reform package has rendered the MKG functionless. Political Islam and ethnic separatism remain to be serious threats. The appointment of a civilian secretary-general to that body would politicize it. One should not have weakened the MGK for the sake of democracy and the EU (Milliyet, 16 August 2003).

At the time, commentators in Turkey were of the opinion that in addition to General Kılınç, General Aytaç Yalman, Commander of the Land Forces, General Cumhur Asparagus, Commander of the Air Force, General Şener Eruygur, Commander of the Gendarmerie, General Çetin Doğan, Commander of the First Army, and General Hurşit Tolon, Commander of the Aegean Army, also had strong reservations about 
the reform packages in question and, thus, were critical of the AKP government. General Yalman declared, 'politicians, too, should conform to the EU criteria' (Hürriyet, 31 August 2003). General Doğan harshly criticized the Prime Minister, for the latter's 'hostile policies and attitudes toward the armed forces' (Milliyet, 6 August 2003). General Asparagus, in his farewell speech on the eve of his retirement on 31 August 2003 pleaded with those whom he was leaving behind to carry the flag:

Neither the EU nor those who pose as Turks should be afraid of Atatürkism. My cocommanders, please continue to safeguard the secular-democratic Turkish Republic, which is an indivisible entity with its territory, nation, language, and culture (Milliyet, 28 August 2003). ${ }^{10}$

Did the generals who had such strong reservations about the EU also object to Turkey becoming a full member of the EU? At least Kilınç, on an earlier occasion, had given the impression that he was against Turkish EU membership. At a seminar, attended by both civilians and officers, he had suggested that 'Turkey should perhaps seek other alignments with such countries as Iran and Russia' (Hürriyet, 16 May 2003). Later, however, Kılınç pointed out that that he was not against the EU as such. General Yalman, too, pointed out that his views should not be taken to mean that he was against the EU. According to him:

the TSK [Türk Silahl Kuvvetleri-Turkish Armed Forces] had played a pioneering role in the integration of Turkey to the West, and therefore nobody should think that the TSK could be against the EU and democracy (Milliyet, 29 September 2003).

How did the office of the chief of staff react to such views? Following Kılınç's suggestion that Turkey should perhaps think of developing close relations with Iran and Russia, Chief of Staff General Hilmi Özkök pointed out that, 'the office of the secretary-general of the MGK is affiliated to the prime ministry, not to the office of the chief of staff' (Sabah, 27 May 2003). The next day he disclosed what was in his mind in a more straightforward manner: 'Whatever Tuncer Pasha said are things he himself said' (Hürriyet, 28 May 2003). Then Özkök felt the need to further elaborate on the issue. This time, the message he gave was clear-cut: his office did not share the opinions expressed. At the same time, as chief of staff of a military that valued the principle of hierarchy, Özkök seemed to avoid giving the impression that there has been a lapse in that regard:

\begin{abstract}
At this time my co-commanders are disclosing their views on a number of issues. One should take those statements as their personal opinions. I am not saying that my co-commanders' views are wrong. Nor am I saying that they are right. Let me, however, point out that it would have been better if they had made those views public after they had retired (Milliyet, 26 August 2003; emphasis added).
\end{abstract}

Second, General Özkök, as chief of staff of a military that had always placed great emphasis on its cohesiveness, rejected the claims made by an Istanbul daily, Cumhuriyet, that there was a rift among the generals on the one hand, and between the generals and lower-ranking officers, on the other. 


\section{Heper}

How could there be hawks and doves in the military or a conflict of opinion between the ranks? The views expressed by my office are based on careful scrutiny of the issues, and reflect the collective wisdom of the TSK (Sabah, 27 May 2003; emphasis added).

In the wake of this statement by Özkök, General Hakkı Karadayı who was chief of staff during the 1997 political crisis and who had diligently conformed to his principle of not making any statements concerning the military after his retirement, ${ }^{11}$ this time acted against that principle and pointed out that the statement made by Özkök did reflect the way decisions are made in the TSK, and that everybody abides by those decisions (Hürriyet, 9 September 2003). General Kenan Evren, who had led the 1980 military intervention as chief of staff, corroborated what both Özkök and Karadayı had stated. According to Evren:

There are always differences of opinion in the military. Officers freely express their opinions. Some even do not mince their words; they criticize chief of staff, too. Chief of staff listens to everybody and then makes a decision that would be binding on everybody. Once in a while, some officers publicly say what they are not supposed to say. However, what they say does not shape the decisions and policies of the office of the chief of staff. ${ }^{12}$

Evren said the last sentence with a smile. However, for Özkök, a chief of staff on active duty, the issue was much more serious than Evren made it seem. Özkök tried to make sure that people in Turkey and abroad should not presume there was a rift within the TSK nor take seriously statements that had not been approved by his office. At the same time, he wanted send a message to generals about who was the boss, and what others were supposed to say and not supposed to say:

Why should there be conflict of opinion within the military? Other generals know the views of the chief of staff. It is also clear who can disclose those views: the chief of staff himself, the deputy chief of staff, and the secretary-general of the office of the chief of staff, and, concerning their own forces, the commanders of the army, navy, air force, and gendarmerie (Milliyet, 28 May 2003).

Özkök too had reservations about the EU. This was reflected in some of his statements, such as the one he made at an MGK meeting, in which he argued that Turkey should reform its legal system to conform to the EU criteria without ignoring the republican characteristics of its state. Yet, having made that statement at a MGK meeting, he seemed to be 'conveying his views' rather than insisting that government should always act along the lines the military deems appropriate. By making this statement, Özkök was, in all probability, also trying to act in a responsive manner to what seemed to be a widespread dissatisfaction within the military concerning the weakening of the MGK. In fact, on an earlier occasion Özkök, had declared:

If some members of the military are uncomfortable with some policies of the government, we all become uncomfortable (Milliyet, 26 May 2003).

However, compared to General Kılınç and other generals in question, General Özkök and his then deputy General Büyükanıt, who at the time of writing was Commander of 
the Land Forces and expected to become chief of staff in 2006 (when Özkök will retire), have displayed an unmistakable enthusiasm for Turkey joining the EU as a full member. In the last analysis, both see it as the final stage of Turkey's European project. According to Özkök:

...the TSK had played a pioneering role in the modernization of Turkey. Thus, the TSK always favours Turkey's becoming an EU member (Milliyet, 10 January 2003).

And according to Büyükanıt, the TSK is:

an unyielding defender of ... a secular and democratic state. This fundamental stance of the military is in full concert with the EU worldview (Sabah, 30 May 2003).

Significantly, Özkök's stance of not opposing the weakening of the MGK seems partly to have been motivated by the fact that to do otherwise would have stood in the way of Turkey's full membership in the EU. But he has also had second thoughts about the influential role the military has played in Turkish politics since 1960. Özkök thinks that the military should have greater confidence in the judgement of the people to safeguard the Republic. In his opinion, in order to bring about such a change, the military should leave behind its traditional way of thinking:

The military intervened on May 27 [1960], March 12 [1971], and September 12 [1980]. Were these interventions successful? No! If they had been successful, those politicians who were banned from politics could not have returned to active politics. But they did return to active politics; they even became prime ministers and presidents. This means that military interventions should not be looked upon as panaceas for the ills Turkey faces. From now on, we should have greater trust in the people. The TSK should have a new vision. Otherwise, we cannot distinguish ourselves from those who only try to emulate the past. Our officers should have stronger intellectual capabilities. We should attain more mature thought patterns (Hürriyet, 27 August 2003). ${ }^{13}$

Four days later, apparently aware of the fact that what he was proposing was not in conformity with Atatürkism as interpreted and internalized by the bulk of the officer corps in Turkey, Özkök came up with what might be considered in the Turkish context as another revolutionary idea-that of taking a fresh look at Atatürkism itself:

The TSK is saddled with new and difficult tasks as a consequence of the reactionary and separatist movements that continue to become even more critical as time goes by. On the other hand, new democratic values and changing concepts of sovereignty make it necessary that we come up with new ideas and doctrines for the better fulfilment by the TSK of the arduous tasks in question.... The Atatürkist way of thought, which is free from dogmas and based on reason and science, can and should be reinterpreted. Only then will Atatürkism continue to be a guiding light for the future generations too (Milliyet, 31 August 2003).

As would be expected, the three remaining members of the old guard (after the others retired at the end of August 2003) did not agree. General Yalman stated that: 
Atatürkism is the pinnacle of modernity. Despite some unfortunate statements to the contrary, it is not a pro-status quo worldview. Atatürkism is a progressive worldview; it does not conflict with the requisites of our times (Milliyet, 30 October 2003).

General Eruygur, in turn, argued that:

Atatürkism is based on reason and science. It would not make sense to claim that it remains focused on the Turkey of 1923 (Milliyet, 30 October 2003).

The third member of the group, General Tolon, indirectly accused the chief of staff of acting in an unpatriotic manner, because the latter had gone along with the government's 'conciliatory policy' regarding the settlement of the Cyprus problem. The latter was critical for Turkey to obtain a date from the EU for the start of its accession negotiations (Hürriyet, 22 January 2004). ${ }^{14}$

However, despite their differences with their chief of staff, all three commanders have continued to serve strictly in accordance with the directives and guidelines set by the office of the chief of staff. Moreover, during the critical negotiations between the Greek and Turkish Cypriots on the future of the island (February 2004), General Yalman, who has been a hawk on the issue, adjourned his scheduled visit to the Turkish military contingent on the island, because this could have been interpreted as a public criticism of the chief of staff after the latter had adopted a more conciliatory attitude on the issue. In his turn, General Tolon retracted his statement about the chief of staff acting in an unpatriotic manner.

\section{Conclusion}

In the post-1999 period, Turkey has made steady and significant progress from rational towards liberal democracy. Civil-military relations in Turkey, which stood in 'fragile concordance' in earlier years (Narl 2000), came closer to full concordance. Turkey's wish to become a full member of the EU and the strict EU acquis provided a big push to this process. Yet this transition was greatly facilitated, if not enabled, by Turkey's European vocation going back to the eighteenth century, the Turkish military's conviction that at least in principle the last word belongs to civilians and its ability to learn from past experience, and the relatively responsible and effective governments that Turkey has had since 1999.

It should be mentioned in passing that the bulk of the civil societal associations, led by the Association of Industrialists and Businessmen of Turkey (Türkiye Sanayiciler ve İşadamları Derneği-TÜSİAD), also actively supported the tradition of republican Turkish politics. For understandable reasons, these associations, in particular TÜSİAD, wish to see political stability. They have traditionally thought that political stability will prevail if the threats of political Islam and, in particular, of ethnic separatism can be successfully tackled if Turkey had a more liberal and democratic system of government. And in their view, Turkey's accession to the EU would be the best guarantee for the further flourishing of liberal democracy in Turkey. In the process, as compared to the military, civil societal associations became even 
more ardent champions, again in the terminology of the introduction to this File, of discursive Europeanization, or increased reference to the EU and other countries in public discourse.

The starting point of Europeanization in the Ottoman Turkish polity was the Europeanization of identity. This emerged at first as state Europeanization rather than societal Europeanization. This in turn led to political Europeanization or the Europeanization of political processes. The state version of the Europeanization of identity could only lead to the consolidation of democracy, or democracy becoming the 'only game in town'. Turkey's attempts to gain accession to the EU made possible considerable progress towards the next stage of democratization, that is, that of deepening democracy. At this stage of Europeanization, we witnessed both the further liberalization of the political regime and the increased democratization of civil-military relations; the latter process facilitated the former, though to this day it is still not an entirely resolved issue. The discursive Europeanization that one observes in the case of civil societal organizations targets this latter problem, in addition to that of enabling Turkey to obtain a date from the EU for the start of the accession negotiations.

\section{Notes}

[1] The author is grateful to the Turkish Academy of Sciences for the support that made research leading to this article possible.

[2] Unattributed quotes in this article indicate typical thoughts of the actors referred to, rather than concrete references.

[3] However, officers have always had sympathy for a democracy that displayed primary concern for the long-term interests of the community.

[4] Some students of Turkish politics have perceived officers' low pay as another factor leading to the 1960 intervention.

[5] It should also be pointed out in passing that in the wake of the 1980 military intervention, military officers attempted to make use of Islam as an antidote against the hard ideologies championed by the ultra-right and radical left during the previous two decades.

[6] This has been the thinking on the part of generals from the 12 March 1971 military intervention onwards. See inter alia, Harris 1988.

[7] This view was expressed to the author by Admiral Nejat Tümer, a member of the 1980 junta, during an interview in 1983.

[8] Earlier, Özal had played a critical role in the appointment of Torumtay as chief of staff over the preferred candidate of the armed forces. For a full account of the Özal-Torumtay confrontation, see Torumtay 1994.

[9] The Office of the Chief of Staff pointed out that if a general would be appointed as the secretary-general of the MGK, that office too should be consulted. The government amended the bill accordingly.

[10] In Turkey, the idea that the country is 'an indivisible entity with is territory, nation, language, and culture' is an important dimension of the so-called 'Atatürkist nationalism', which is imparted to future officers in military schools they attend. On how officers in Turkey are socialized into Atatürkism in general, see Birand 1991, in particular pp. 52-67.

[11] The author became aware of this principle of General Karadayı when some years ago he asked Karadayı if he would kindly agree to an interview by an American PhD student who was 


\section{Heper}

studying civil-military relations in Turkey. Karadayı did not agree to the interview and told the author that it was his principle not to give such interviews.

[12] Author's interview with Kenan Evren, Marmaris, 14 August 2003.

[13] If indeed the military comes to have greater 'trust in the people', that trust would be lodged in the representatives of the people, not in the people themselves, for civil society in Turkey is still in its infancy. It is true that there is a great deal of civil societal activity in Turkey; however, Turkish civil society is yet to impinge continuously and effectively on political decision makers.

[14] From the late nineteenth century onwards, the military acted as 'subject' as well as the 'object' of modernization taken as Westernization. As far as this articulate group of generals were concerned, the EU as the 'West' was now posing a threat to the traditional guardianship role of the military, for the reforms vis-à-vis the MGK would have made it difficult for the military to justify the role they were used to playing in the Turkish polity by resorting to the argument that they were fulfilling a duty assigned to them by the Constitution and other laws.

\section{References}

Birand, M. A. (1991) Shirts of Steel: An Anatomy of the Turkish Armed Forces, I.B. Tauris, London and New York.

Harris, G. (1988) 'The Role of the Military in Turkey: The Guardians or Decision-Makers?', in State, Democracy and the Military: Turkey in the 1980s, eds M. Heper \& A. Evin, Walter de Gruyter, Berlin and New York, pp. 177-200.

Heper, M. (2001) 'Turkey: Yesterday, Today and Tomorrow', Journal of Southeast European and Black Sea Countries, vol. 1, no. 3, pp. 1-19.

Heper, M. (2002) 'The Military-Civilian Relations in Post-1997 Turkey', in Globalization of CivilMilitary Relations: Democratization, Reform and Security, eds G. C. Maior \& L. Watts, Enciclopedica Publishing House, Bucharest, pp. 52-70.

Heper, M. (forthcoming) 'Conservative-Democratic Government by Pious People: The Justice and Development Party in Turkey’, in Blackwell Companion to Contemporary Islamic Thought, ed. I. Abu-Rabi, Palgrave, London.

Heper, M. \& Güney, A. (2000) 'The Military and the Consolidation of Democracy in Turkey: The Turkish Case', Armed Forces and Society, vol. 26, no. 4, pp. 625-647.

Karaosmanoğlu, A. L. (1993) 'Officers: Westernization and Democracy', in Turkey and the West: Changing Political and Cultural, eds M. Heper, A. Öncü \& H. Kramer, I.B. Tauris, London and New York, pp. 19-34.

Müftüler Baç, M. (2003) 'The New Face of Turkey: The Domestic and Foreign Policy Implications of November 2002 Elections', East European Quarterly, vol. 37, no. 4, pp. 421-438.

Narl, N. (2000) 'Civil-Military Relations in Turkey', Turkish Studies, vol. 1, no. 1, pp. 107-127.

Sakallığlu, Ü. C. (2002) 'The Military and Politics: A Turkish Dilemma', in Armed Forces and Society in the Middle East: Politics and Strategy, eds B. Rubin \& T. A. Keaney, Frank Cass, London, pp. 189-205.

Sartori, G. (1987) Theory of Democracy Revisited. Part Two: The Classical Issues, Chatham House, Chatham, N.J.

Torumtay, N. (1994) Orgeneral Torumtay'in Anıları [General Torumtay's Memoirs], Milliyet Yayınları, Istanbul. 